\title{
Impact of Macroeconomic Factors on Banking Profitabilty
}

\author{
Lutfullah Lutf (Corresponding author) \\ M.Phil. in Economics, and Executive Master in Economic Policy from the University of \\ Central Asia, Senior Fellow at Center for Studies and Research, Kabul, Afghanistan \\ E-mail: 1lutf48@gmail.com
}

Hafizullah Omarkhil

M.Phil. in Islamic Banking and Finance

E-mail: hafiziiui@gmail.com

Received: April 30, 2018 Accepted: May 30, 2018 Published: June 22, 2018

doi:10.5296/ifb.v5i1.13080 URL: http://dx.doi.org/10.5296/ifb.v5i1.13080

\begin{abstract}
This study comparatively focuses on the impact of macroeconomic determinants and the internal indicators on performance of conventional and Islamic banks in Pakistan. It evaluates the differential effects of macroeconomic variables and bank specific variables with a baseline study of five banks from each system. To determine the short-run and long-run impact of these factors, co-integration \& general to specific approach are adopted. This study also considers bank specific and macroeconomic variables in two separate models (Return on Assets and Return on Equity). Our objective is to find the extent to which each system of banking is performing in the country. The results indicate that in the long run, Gross Domestic Product, and inflation, is positively related to performance, while Interest rate has no effect on the performance of banking sector in Pakistan. Similarly, bank size, capital adequacy, expenses, interest income and non-interest income are the bank related factors that significantly influence the performance of financial sector.
\end{abstract}

Keywords: Macroeconomic factors, Banking profitability, Conventional \& Islamic banking 


\section{Introduction}

Federal Government of Pakistan is interested to promote and support Islamic Banking. The government has established a committee, which will recommend real sharia compliant Islamic banking (Tribune, 2013), (Note 1) As the believers of Islam, Islamic economists \& bankers are also responsible to struggle, offer and provide a Sharia compliant substitute of interest based financial system. According to the verdict of the Supreme Court of Pakistan (1999) regarding promoting Islamic financial system, it is very important to find out the ways through which Islamic Banking can be promoted. With their cooperation, the contemporary Islamic economists, bankers, finance experts and Muslims jurists have developed the current Sharia compliant banking \& financial system, but the structure requires further development. Despite, the satisfactory growth of Islamic banking, the conventional banks are still dominant in the country. At this stage it is very important to investigate the impact of macro-economic dynamics that would intensify the performance of Islamic banks because the understanding of the performance of financial institutions is essential and for the strength and stability of the economy.

The rapid growth of Islamic banking and its important role in the economies of Malaysia, Indonesia and Pakistan make it imperative to have a broader understanding of banking performance and its macroeconomic drivers. The existing literature, which focuses on the determinants of banking sector have only considered one type of banking system and ignored the others. Secondly, most of the studies did not consider bank specific and macroeconomic variables collectively. Thus, previous studies are inconclusive in their findings and conclusions, particularly in Pakistan. Therefore, the aim of this study is to fill the gap in the existing literature by examining bank-specific and macroeconomics variables collectively. Moreover, a comparative study between the two systems is required to identify the differential impact of macroeconomic variables on the financial sector.

\subsection{Problem Statement}

In Pakistan, conventional and Islamic banks operate simultaneously, although the former is still dominant. However, the Government of Pakistan has increased its interest in promoting and supporting Islamic Banking. First, by establishing sharia compliancy committees (Tribune, 2013), (Note 1). And second, by encouraging scholars and bank professionals to find avenues of offering and providing Sharia compliancy substitute of interest based financial system in line with the 1999 Supreme Court of Pakistan verdict. In this regard, Sharia compliancy banking \& financial system has been developed, but the structure requires further development. Despite, the support and promotion of Islamic banking system, their overall performance remains lower in comparison to their counter parts, due to among others: First, the requirement to apply strict sharia rules to develop or modify products and services, an issue raising operational costs; second, their small size in the financial sector (Chapra, 2007). Empirically, size plays a prominent role in bank performance (Miller \& Noulas, 1996). Finally, almost all Islamic banks are domestically owned. Empirical evidence suggests that foreign-owned banks are more efficient in technical side than the domestic ones (Mathews \& Ismail, 2006). 
The global rapid growth of Islamic banking and its important role in the economies warrants a broader understanding of their performance and macroeconomic drivers. Existing literature on the determinants of banking sector have mostly focused on conventional banking. Additionally, in most of the studies bank specific and macroeconomic variables were not collectively analyzed. Thus, there are inconclusive findings and conclusions, justifying continuous studies to fill the gaps. In our attempt to fill these gaps, we utilize the co-integration and general to specific approaches on quarterly series data (2007 to 2015) from State Bank of Pakistan and International Financial Statistics 2014.

\subsection{Importance of the Study}

This analysis is important on the following grounds: 1) It will aid stakeholders to understand the factors that may influence the performance of Islamic banks. 2) The results will provide valuable input to financial sector managers regarding the impacts of government policies and macroeconomic factors on their returns, market requirements and objectives. 3) The comparison will provide valued information to pertinent parties, for example bank management and bank controllers in building a competent managing policy for Islamic banks to earn higher profits.

\section{Literature Review}

The review of the literature is performed thematically considering bank specific and macroeconomic variables. The basis of this approach is to avoid missing variable bias and to ensure reliability of results.

\subsection{Measures of Performance}

Performance ratios that are mostly used in the literature include return on assets (ROA) and return on equities (ROE) (Iqbal et al., 2005). In this study, the same two performance ratios are used as proxies for the measurement of performance. Since the ratio of ROA has proved to be the core indicator for the measurement of performance of banks (Golin, 2001), many of the researchers used ROA. Bashir (2000) concluded that ROA is the perfect indicator of banking sector efficiency. It is a common measure for the performance of management (Ross et al, 2005); (Athanasoglou, Brissimis, \& Delis, 2008). This implies that how effectively the bank's assets were managed to bring about higher profits (Naceur, 2003). Assets are owned by an individual or business to generate inflow of money. For banks, loan and securities are considered as assets which are used to generate most of a bank's income. Some other researchers have considered ROE to measure the performance of banking sector ROE (Rose, 2002). This shows that how excellently a bank's administration is performing to convert owner's equity into net earnings. A high ratio of ROA \& ROE indicates higher managerial efficiency of the bank and the opposite is true for lower ratios. Therefore, in the present study both ROA and ROE is used to quantify the profitability of banking sector.

\subsection{Macroeconomic Variables and Bank Performance}

Macroeconomic variables such as GDP growth, interest rate, inflation, money supply and exchange rate are not in the control of the bank's management (Khrawish, 2011). Gizycky, (2001), studied the relationship between bank profitability and bank resilience in the wake of 
macroeconomic contraction in Australia. Similarly, Athanasoglou and Dalis (2005), analyzed the impact of fluctuations in macroeconomic variables on banking earnings in Greece. The results show that the inflation has significant positive impact on bank's utilities which are proxies for returns on equities (ROE) and/or returns on asset (ROA). In the context of macroeconomic management, Clair (2004) in his study for Singapore found that on average two-thirds of the bank's performance is closely linked to the performance of macroeconomic variables. Some studies suggest that there is no direct correlation between changes in bank's performance and the business cycle.

Studies that have analyzed the impact of GDP on banking profitability have mixed conclusions. For instance studies by Athanasoglou (2005); Naceur (2006) and Teng (2012) have confirmed that it has no significant relationship with the profits of bank. By contrast, the works of Bikker (2002); Athanasoglou et al., (2008); Uhomoibhi (2008); Kosmidou (2008); Srairi (2009); Sufian and Habibullah (2010); and Kharawish et al. (2011) concluded that there is a positive the profitability of banks and GDP.

The impact of inflation on profitability of financial institutions is inconclusive. A study by Revell (1979); Haron (1996) and Staunton (2002), found inflation to be an important determinant causing variations in bank's performance. However, Boyd et al., (2000); Kosmidou (2008); Staikouras et al. (2008); and Walid et al. (2011) found negative relations between ROA and inflation rate. If the inflation is anticipated, the interest rate could be adjusted according to the accordingly, and thus will gain more profits. In that case, the impact of inflation on bank profitability would be positive since the banks are capable to incorporate these impacts into its operating expenses to enhance earnings. However, if inflation is unanticipated, the bank profitability could be negatively affected by inflation or the effect may be less significant.

Regarding another variable interest rate, similar conclusions are observed. Athanasoglou, and Delis (2008). Nienahaus (1983) discovered that the returns of Islamic Bank are directly associated with the loan rates of conventional system, although he was unable to provide empirical backing to his arguments. Khan (1983) also failed in the similar attempt. Furthermore, Haron (1996) found that the impact of interest rate on the performance of Islamic and conventional banks was positive and significant. Haron \& Ahmad (2000) confirmed and supported these findings. However, Hassan \& Bashir (2003), verified that interest rate is negatively related to the profitably of banks.

The effect of money supply another macroeconomic variable provides inconclusive findings on bank performance. The studies by Haron (1996); Azmi (2004); Krakah \& Ameyaw (2010), Kutsienyo (2011) and Teng et al. (2012) confirmed significant and positive correlation between money supply and the revenues of banks. On the contrary, other analysts notably Badaruddin et al. (2009); Sofian \& Habibullah (2009) and Kutsienyo (2011) established negative relationship of growth in money supply and bank income.

\subsection{Bank Specific Determinants and Banking Performance}

Institutional factors both non-financial and financial statements are controlled by bank management, (Note 2). Bank specific factors that are widely considered in the previous literature include bank size, capital adequacy ratio, liquidity ratio, deposit to asset ratio, net 
interest margin, Loan loss reserve ratio, and cost to income ratio.

Asset size measures the related economies or diseconomies of scales. Literature confirmed positive relationship between asset size and bank performance Kahf, (2004); Al-Tamimi, (2005); Burki \& Niazi, (2006); Sufian, (2009); Gropp \& Heider, (2010); Asma et al., (2011); Idris et al., (2011); Housni, et al., 2011. On the other hand, a large number of studies found negative relation between asset and profitability. Their view is that large size increases the organizational process which decreases efficiency. A number of studies like Emery, (1971) and Smirlock, (1985) detect insignificant relation between asset size and profitability.

For capital adequacy ratio, Naceur, (2003); Bashir, (2003); Haron (2004); Kosmidou, (2007); Kutsienyo, (2011); Javaid, et al., (2011) and Gul, et al. (2011) argued that as capital increases, the less risky it gets for the banks and similarly thought that greater capital ratio is a guarantee of safety for banks. Berger, (1995) stated that the effect of capital on performance is influenced by the particular situations of time period considered. Capital positively impacts performance when monetary conditions of banks are considered risky, and adversely influences the performance in regular circumstances because of the marginal charges of funds.

Liquidity risk produces similar results, (Note 3). Studies by Eichengreen \& Gibson, (2001). Bourke (1989); Kunt and Huizingha (1997); Kosmidou et al. (2005); Kutsienyo (2011); Akhter et al. (2011) and Javaid, et al. (2011) found liquidity risk to be positively related to bank profits. However, Guru et al. (1999); Hasan and Bashir (2003) and Husni, et al. (2011) studies discovered the negative impact of liquidity risk on ROA. The middle ground is provided by Vong \& Chan (2005) whose work suggests that higher liquidity ratio does not necessarily generate higher profits.

On deposit liability, Javaid, et al. (2011) and Gul, et al. (2011) studies found a positive and significant of this variable on profitability, (Note 4). By contrast, some other studies concluded that as term and investment deposits have a reasonably higher price of funds, the broader the deposit base, the higher may be the financing charges and thus the lesser gains for banks (Ommeren, 2011). Mustafa et al., (2012) discovered that deposits are negatively related to ROA in Pakistani banking industry, partly due to intense competition in the financial sector. Contradicting the positive - negative nexus, Singh \& Chaudhary, (2009) found no relationship them and bank profitability.

With regard to efficient cost management, (Note 5), studies by Berger (1995); Athanasoglou et al., (2005); Bashir (2003), Haron (2004); and Ahmad (2011) concluded that expenses of Islamic banks have positive impact on ROA. However, Berger (1997); Sufian \& Habibullah (2010) and Kusmidou et al., (2005) found an adverse relationship between expenses and profitability.

With regards to bank income, similar observation is echoed. Interest income of conventional was found to leading to additional earnings. Non-interest income or profit sharing ratio of mostly Islamic banks has both positive and negative relations with profitability. Earlier studies by Gischer and Juttner (2001) found an adverse relationship between non-interest income of banks and profitability. However, recent study by Ameyaw \& Karkrah (2010) confirmed to the contrary. 


\section{Methodology, Data \& Variables}

\subsection{Methodology}

The model adopted in this study is General to specific. This is done to minimize omitted variable bias and to reduce on insignificant estimates.

\subsection{General to Specific (G2S) Approach}

Following other models, we include all possible determinants of ROA and ROE to come up with a parsimonious model which will yield consistent and unbiased estimates.

A few of the insignificant variables in the general model are checked for their significance by multiple regression model and application of the Wald Restriction Test. Those that appears to be insignificant are excluded from the study.

The models of bank profitability are described as follow:

$$
\begin{aligned}
\operatorname{ROA}_{t}=\beta_{o}+ & \beta_{1}(G D P)_{t}+\beta_{2}(I N F)_{t}+\beta_{3}(I N T)_{t} \\
& +\beta_{4}(M 2)_{t}+\beta_{5}(S I Z E)_{t}+\beta_{6}(C A Q)_{t}+\beta_{7}(L I Q)_{t}+\beta_{8}(C O S T)_{t}+\beta_{9}(D A R)_{t} \\
& +\beta_{10}(L L R)_{t}+\beta_{11}\left(I N T^{*}\right)_{t}+\beta_{12}(N I I)_{t}+e_{t} \\
\operatorname{ROE}_{t}=\beta_{o}+ & \beta_{1}(G D P)_{t}+\beta_{2}(I N F)_{t}+\beta_{3}(I N T)_{t} \\
& +\beta_{4}(M 2)_{t}+\beta_{5}(S I Z E)_{t}+\beta_{6}(C A Q)_{t}+\beta_{7}(L I Q)_{t}+\beta_{8}(C O S T)_{t}+\beta_{9}(D A R)_{t} \\
& +\beta_{10}(L L R)_{t}+\beta_{11}\left(I N T^{*}\right)_{t}+\beta_{12}(N I I)_{t}+e_{t}
\end{aligned}
$$

Where: $\beta_{1}-\beta_{12}$ are coefficients for the respective dependent variables. From $\beta_{1}-$ $\beta_{4}$ represent the co-efficient of macroeconomic variables, and $\beta_{5^{-}} \beta_{12}$ represent co-efficient of bank specific variables.

\subsection{Avoiding Spurious Regression by Co-Integration}

Time series data often contain non-stationary series which may give rise to spurious regression. To avoid spurious regression, this work adopts the Engle-Granger two-step co-integration method to examine whether a co-integrating relation exists between bank specific and macroeconomic variables with bank performance. After testing co-integration, we estimate short-run impact of changes on bank performance and the speed of error correction, if any, between the variables. The proxy used for bank performance is ROA and ROE. The Engle-Granger method involves the following steps.

The first stage is to test, whether a range of data contain unit roots in the individual time series. Unit root tests are used to determine whether time series exhibit mean-reverting behaviour by showing their order of integration. If a pair of time series, such as $C A Q$ is $I(1)$ variable, then co-integration techniques can be used to model their long-run relationship. The Augmented Dickey-Fuller (from Fuller, 1976 and Dickey and Fuller, 1979) is used to examine the order of integration. The ADF test is estimated as:

$$
\Delta Y_{t}=\alpha_{o}+\beta_{t}+\alpha_{1} Y_{t}+\Sigma b_{1} \Delta Y_{t-1}+\varepsilon_{1}
$$

The null hypothesis is that $Y_{t}$ which contains unit root, which implies that $\alpha_{1}=1$, contrary to alternate that a series does not contain unit root, which implies that $\alpha_{1}<1$. Dickey and 
Fuller (1981) offer collective distribution function for an ADF estimates. But if the calculated figure of a coefficient of $\alpha 1$ is less than the ADF t-critical, the study does not accept the alternate hypothesis that $\alpha_{1}=1$, in which case $Y_{t}$ does not contain unit root. Otherwise accept the null hypothesis.

Once the order of integration of the series are confirmed $I(\mathrm{I})$, the study then move to the long-run relationship, e.g., run the regression on equation (2). In order for these variables be co-integrated, estimated residual from the equation (1) should be stationary (i.e., $\mu_{t} \sim 1(0)$ ).

The residual-based unit root test is the best way to observe, if the residuals from equation (2) are unit root. If they are stationary, then the series are co-integrated. If the residuals are not stationary, there is no co-integration rejecting the null hypothesis of a unit root test, therefore, is evidence in favour of co-integration (Engle and Granger, 1987). Residual-based test is estimated as follows:

$$
\Delta \mu_{t}=\alpha_{1} \mu_{t-1}+\varepsilon_{t}
$$

Where, $\Delta \mu_{t}$ are the estimated first differenced residual, $\mu_{t-1}$ are the estimated lagged residuals, $\alpha_{1}$ is the parameter of interest representing slope of the line, $\varepsilon_{t}$ are errors obtained from the regression.

\subsection{Error Correction Model}

The study estimates the Error Correction Mechanism (ECM). ECM is based on the assumption that two or more time series exhibit an equilibrium relation that determines both short-run and long-run behaviour. According to the Granger representation theorem, for any set of $I(\mathrm{I})$ variables, error correction and co-integration are equal representations. In other words, if a number of variables, such as $C A Q$ and $R O A$, are co-integrated there will be ECM relating the variables. The ECM is estimated thus:

$$
\Delta \pi=\alpha_{1}+\alpha_{1} \Delta X_{t}+\alpha_{2} \mu_{t-1}+\varepsilon_{t}
$$

Where, $\Delta$ denotes the first difference operator, $\Delta X_{t}$ independent variables, $\alpha_{2}$ is represents a coefficient of one period lagged value of an error term from the co-integrating regression in equation(2), $\mu_{t-1}$ is the residual from equation (1) and $\varepsilon_{t}$ is random error term. While $\alpha_{1}$ measure the short-run impact, $\alpha_{2}$ is the error correction term, which captures the rate at what $\Delta \pi$ adjusts to the equilibrium state after a shock. The coefficient of $\alpha_{2}$ should be negative in sign for the series to converge to long-run equilibrium. Negative and statistically significant $\alpha_{2}$ coefficient is regarded as convincing evidence and confirmation for the existence of co-integration found in the co-integrating regression (Engle and Granger, 1987). Additionally, the size of $\alpha_{2}$ is an indication of the speed of adjustment towards equilibrium. A lower coefficient of $\alpha_{2}$, tending towards -1 , represents that adjustment speeds is quicker; bigger values, tending to 0 , indicate a slower adjustment process; while positive values would imply that the series diverge from a long-run equilibrium path.

\subsection{Data}

Quarterly time series data for ten banks (five conventional and five Islamic banks) is used for 
the period 2007-2015 is collected from the quarterly reports of SBP, financial statements. Data for macroeconomic variables is obtained from International Financial Statistics (IFS) 2014 and Pakistan Economic surveys. Bank Selection Criteria: the study selected our sample size from the banking survey of KPMG, 2015. KPMG conducts a survey every year and they classify the banking sector into three major categories: small, medium and large size banks. This classification is based on the bank's loans, size, assets and deposits. Till to date none of the Islamic bank have achieved the status of large bank as they are newly established and require time. Therefore, this stud uses this as a benchmark for selecting our banking sample. Since our aim is to comparatively evaluate the two types of banks, the selection should also be based on the size of banks. Presently, there are five full-fledged Islamic banks operating in Pakistan from which only Meezan Islamic bank is a medium size bank and the remaining four Islamic banks are small size banks. Thus, on the conventional side the study also add one medium size bank and four small size banks (Note 2).

\subsubsection{Dependent Variables}

A number of performance measurement ratios are available in the literatures that are usually used to determine the profitably of banking sector. The ratios include (ROA) and (ROE) (Iqbal et al, 2005). This study also uses ROA and ROE as proxies to measure the performance of banks. In the existing literature, the performance of bank is related to bank specific and microeconomic factors. Micro or banks-specific determinants are mainly influenced by banks' management decisions and policy objective. Following Sufian and Habibullah (2009), and Kosmidou (2008), the left side variables in this study are ROA and ROE. They reflect the income earned on each dollar and show that how effectively the management is utilizing the financial resources of the bank to produce earnings (Hassan \& Bashir, 2003). For banking sector, ROA is largely influenced by the policy decisions a bank makes, and external factors concerning to banking regulations and economic conditions. According to Rivar \& Thomas (1997) the best measure of performance is ROA because it is a healthier indicator of a firm's ability to make profit on the assets portfolio. ROA assesses the profitability performance of total assets and could be treated as measure of financial performance in this study. ROE ratio shows that how effectively the management of the bank converts the shareholders' funds into net returns. The higher the ratio of ROE is better for banks because investors will look for this ratio prior to investing in financial sector. For financial intermediaries, ROA is expected to be lower, that is why most of the banks employ leverage highly to grow ROE so that the bank can compete in the market (Hasan \& Bashir, 2003). The higher ROA and ROE reflect higher managerial efficiency of the bank and vice versa.

\subsubsection{Independent Variables}

\subsubsection{Macroeconomic Variables}

Macroeconomics variables can be regarded as the determinants that cannot be controlled by the management of the banks (Kharawish, 2011). Economic growth is the commonly used macroeconomic factor which can affect the bank performance because it measures the overall 
economic activity. Economic growth is anticipated to influence several elements associated to demand and supply for loans and incoming deposits (Kosmidou, 2008). This implies that default risk decreases in upturn economies and the opposite is true in downturn economic conditions because upturn economic conditions increases demand for banking services and encourages banks to lend more loans and allow them to charge higher margins. In addition, for conventional banks, high interest rate is usually an indication to higher loan rates, and thus higher revenues. Samuelson (1945) and Anbar and Alper (2011) found that interest rate will affect the bank's performance and it is one of the main factors that will affect the profits generated from loans. Conversely, for Islamic banks a high interest rate might affect profitability positively only if a larger portion of Islamic bank's earnings accrues from direct investment, shareholding and/or other trading activities, such as (Murabaha). But, it can also lead to a negative relation with bank performance if the rate of interest decreases the demand for loans (Hassan \& Bashir, 2003). Islamic banks are operating in economies where interest is a common price of funds (Yap \& Kader); therefore, the pre-agreed rate of saving and financing is still subject to the conventional rate of interest and Islamic banks' return rate is tied to conventional interest rate (Kader \& Leong, 2009).

The impact of inflation on bank performance depends on whether banks' wages and other operating expenses increase at faster rate than inflation, it also depends on the maturity of the economy to accurately forecast the future inflation and manage their operating expenditures Revell (1979). Thus, the association between bank performance and inflation is uncertain and is contingent on inflation expectation fully anticipated inflation rate by the bank's management suggests that banks can properly adjust interest margins and thus raise profits. On the other hand, unanticipated inflation may lead to incorrect adjustment of interest margins which may result in lower profits. Higher inflation in the economy can cause the firms to correct its lending and saving policies according to economic environment in order to generate substantial profits (Rasiah, 2010).

On the supply side, money supply is dependent on the monetary policy pursued by the Central Bank. Typically, open-market operations and bank reserve ratio can exert profound influence on the volume of currency in the economy. Excessive growth of money supply indicate a rise in inflation and for that reason inversely affects deposits. This means that as the deposit declines, it reduces the income level of banks. Furthermore, variations in the overall money supply can lead to variations in the country's nominal GDP and inflation. Even though money supply is decided via the state bank's policy, this can be influenced by the behavior of individuals and banks itself.

\subsubsection{Bank Specific Variables}

Bank size is normally used to measure the economies and/or diseconomies of a firm's scale. Economic theory suggests that if an industry is subject to economies of scale, larger institutions would be more efficient and could provide services at a lower cost, ceteris paribus. Such businesses can also design and produce their products at cheaper cost than smaller banks. Thus, if restrictions are imposed, big banks will earn more profits. A positive impact of size can be related with profitability because economies of scale may decrease the 
cost of processing and collecting the information (Boyd, 1993). The most important question that still remains unaddressed is determining the threshold level for bank size. So far no clear argument is available that which may determine a threshold level of bank size and its impact on performance. The general perception at the theoretical level that increasing bank size shows positive impact on performance. However, for extremely large banks, the impact of the size may be negative due to bureaucratic reasons Athanasoglou et al. (2006).

Capital adequacy measures the general shock absorbing capacity of a bank for potential loan asset losses (Samad, 2004). A decreasing trend of this ratio is an indication to risk exposure and capital adequacy problem (Hassan \& Bashir, 2003). Like conventional banks, the capital structure of Islamic banks comprises the following: paid-up capital, surplus or reserves and retained profits. During loss or liquidation, the dues of depositors are paid prior to the shareholders. Hence, the more the capital contributed by the shareholders, the more confident the customers and they shall place more money or deposits at bank. Aburime (2008) concluded that a bank's degree of soundness can be accomplished via high capital requirements that can generate positive net benefits. Capital adequacy requirements generally aim to intensify the strength of domestic banking sector by decreasing the chances of banking disaster and some negative external factors that exists in the financial sector that may cause high risk.

When banks hold a lower amount of liquid assets, they are more vulnerable to large deposit withdrawals. Same as conventional banks, all deposits paid to Islamic banks carry the unqualified obligation to repay cash at whatever time demanded. For investment account facilities, a very short grace period is compulsory prior to any withdrawal. When a large amount of a bank's obligations need to be repaid on demand, it is crucial that the wealth of the institution should be properly managed for meeting demand for cash. If the bank is unable to fulfill such requirements and demands, depositors will not trust the bank anymore and as a result the firm will have no option but to close. As the degree of liquidity and exposure to risk increases, the frequency of return on assets is expected to react negatively. Thus, the more suitable an asset is to fulfill a bank's liquidity needs, the less likely it is to contribute to bank earnings, and vice versa. By adapting this concept into an Islamic banking context, any Islamic bank which holds an excessive amount of liquid assets will be able to meet all its obligations, but will make less profit. Conversely, if the bulk of funds goes into high earning assets and for that reason is illiquid and more risky, they will earn extra profits but at the meantime cannot meet its promises to pay cash when demanded by customers.

Deposits are considered to influence the profitability of banks because it is the primary source of funding. This ratio shows the broad reliable base of funding for banks, which is backed by deposits and not by borrowed funds or equity. It is the major and inexpensive source of funding for banks. Conventional banks compete and attract deposits from three main sources: demand or current deposits, fixed or time deposits and saving deposits.

Practically, no interest is paid on demand deposits. It can be withdrawn by the customer partially or fully. On term deposits high interests are paid, they are kept with the bank for a specific period of time and it cannot be withdrawn without a prior notice to the bank. In 
Islamic banking, three kinds of deposit facilities are available: current, saving and investment accounts. No reward is given to current account holders. While, pre-determined profit-loss rate and annual income influence the reward for saving and investment accounts. Therefore, funds in current accounts are considered cost-free funds. The more funds deposited in savings and investment accounts, the greater the cost to the bank. In case of current accounts, as the number of accounts and deposits increases, the banks earn more profits (Smirlock, 1985). Increase in deposits improves the bank's performance but, it depends upon how the management of the bank is translating its liabilities of deposits to earning assets.

Effective cost management is essential for the enhancement of bank performance. A lower ratio of expense management is a signal of high income for a bank (Dietrich \& Wanzenried, 2011). As high expenditure generally indicates poor profits; therefore, it is likely to impact bank's earning and profits inversely (Kosmidou et al., 2005). (Athanasoglou et al., 2008) suggest that expenses are the outcome of bank management, thus this ratio is presumed to have negative relationship with profits. Like conventional banks, the spending of Islamic bank can also be roughly divided into three kinds: staff salaries, loan loss provisions and some other general expenses. Expenses like zakat payments and payments for income tax are known as legislative expenditures and are not in the hands of bank managers. The amount allocated for loan loss provisions is reflected in the quality of existing financing or in the investments undertaken by a bank.

Interest income implies how efficiently the bank manages its interest earning assets to generate net interest income. Banks with higher operating costs are expected to have higher net interest margins and lower profits (Abreu, 2001). Contrary to conventional bank practices, the use of an interest margin as a measure to increase profitability is not applicable to Islamic banks. Instead, pre-agreed ratio is the proper measure that may be considered for Islamic banks to improve its returns. In the case of investment deposits that operate on the basis of mudaraba and musharak, if the ratio is to the advantage of customer, a bigger portion of gains will flow to their bags, and the opposite is also true.

Ratio of loan loss reserves (RRL) to gross loans is a measure of banks' asset quality or credit risk that indicates how much of the total portfolio has been provided for but not written off. Pretending a similar charge-off policy, the higher the ratio the weaker the loan quality it represents. Flamini et al. (2009) argue that the major source of bank-specific risk is credit risk. Similarly, exposure to credit risk increases if the macroeconomic environment does not perform well because poor economic conditions may raise the number of defaulters. In the long run, a lower credit quality may inversely influence the profitability and performance because the real costs of non-payable loans are expected to be greater for firms with a lesser assets quality than those with better asset quality.

The important components of these incomes are service charges on different types of accounts and facilities and regular fees. This variable is considered in this study to quantify the significance of fee-related services of banks. Fee-based services add income to banks although the income generated from these services in general is lesser as compared to loans. Fee-based services are important for banks because they need to maximize the non-interest 


\section{Macrothink}

income. The success of commercial banks is highly influenced by the changes in interest rate and loan default risk because the major portion of its produced income is from interest related activities. Banks highly dependent on non-interest income can survive a declining trend in their income in these circumstances as these profits are not affected by interest rate variations and the risk of loan defaults.

\section{Empirical Results and Discussions}

\subsection{General to Specific (G2S) Approach}

The results of redundancy or insignificance variables test are tabulated in Table 1.

Table 1. Redundancy test for all variables

\begin{tabular}{|l|c|c|c|c|c|c|c|c|}
\hline \multirow{2}{*}{} & \multicolumn{4}{|c|}{ Dependent Variable = ROA } & \multicolumn{3}{c|}{ Dependent Variable = ROE } \\
\cline { 2 - 9 } Variable & F-Stat & P-Value & F-Stat & P-Value & F-Stat & P-Value & F-Stat & P-Value \\
\hline CPI & 4.992 & 0.002 & 3.443 & 0.061 & 5.783 & 0.000 & 11.246 & 0.000 \\
\hline INT & 10.880 & 0.001 & 32.012 & 0.000 & 7.246 & 0.004 & 8.054 & 0.013 \\
\hline GDP & 13.065 & 0.000 & 7.082 & 0.000 & 11.538 & 0.001 & 8.103 & 0.004 \\
\hline Ln-M2 & 0.984 & 0.183 & 0.632 & 0.332 & 22.582 & 0.663 & 2.222 & 0.231 \\
\hline SIZE & 34.183 & 0.004 & 9.012 & 0.002 & 130.342 & 0.000 & 12.592 & 0.053 \\
\hline CAQ & 4.973 & 0.023 & 5.535 & 0.030 & 11.564 & 0.003 & 5.572 & 0.010 \\
\hline DAR & 15.722 & 0.002 & 8.479 & 0.006 & 0.558 & 0.042 & 4.934 & 0.023 \\
\hline COST & 10.264 & 0.050 & 2.687 & 0.043 & 4.866 & 0.006 & 8.283 & 0.000 \\
\hline LIQ & 0.004 & 0.941 & 0.123 & 0.710 & 2.554 & 0.111 & 0.082 & 0.774 \\
\hline INT* & 21.254 & 0.003 & 136.251 & 0.005 & 10.573 & 0.006 & 72.142 & 0.003 \\
\hline LLR & 1.267 & 0.263 & 2.687 & 0.101 & 0.050 & 0.812 & 2.282 & 0.131 \\
\hline NII & 11.434 & 0.030 & 9.789 & 0.009 & 14.434 & 0.005 & 21.364 & 0.005 \\
\hline
\end{tabular}

In this Table, Money Supply (LogM2) is the only redundant macroeconomic variable. Two bank specific variables namely Loan Loss Reserve (LLR) and Liquidity (LIQ) are observed to be insignificant. Henceforth, the three are dropped from the models.

\subsection{Joint Exclusion Restriction Test}

The results of the Wald test are presented in Table 2. 
Table 2. Joint exclusion restriction test for all variables

\begin{tabular}{|c|c|c|c|c|c|c|}
\hline Islamic Banks & \multicolumn{3}{|c|}{ Independent Variable $=$ ROA } & \multicolumn{3}{|c|}{ Dependent Variable $=$ ROE } \\
\hline & & F-Stat & P-Value & & F-Stat & P-Value \\
\hline Macroeconomic & LM2, & 0.51 & 0.60 & LM2, & 1.65 & 0.19 \\
\hline Bank Specific & LLR, LIQ & 0.63 & 0.53 & LLR, LIQ & 1.30 & 0.27 \\
\hline Combined-Restriction & LM2, LLR, LIQ & 0.57 & 0.67 & $\begin{array}{l}\text { LM2, LLR, } \\
\text { LIQ }\end{array}$ & 1.24 & 0.29 \\
\hline Conventional B & \multicolumn{3}{|c|}{ Dependent Variable $=$ ROA } & \multicolumn{3}{|c|}{ Dependent Variable $=$ ROE } \\
\hline Macroeconomic & LM2, & 0.64 & 0.54 & LM2, & 3.20 & 0.14 \\
\hline Bank Specific & LLR, LIQ & 0.84 & 0.50 & LLR, LIQ & 1.17 & 0.31 \\
\hline Combined-Restriction & LM2,LLR, LIQ & 0.88 & 0.36 & $\begin{array}{l}\text { LM2, LLR, } \\
\text { LIQ }\end{array}$ & 2.57 & 0.11 \\
\hline
\end{tabular}

The results in the above table indicate that all three (M2, LLR \& LIQ) variables can be dropped from both models as they are highly insignificant.

\subsection{The Simple Model}

After dropping the highly insignificant variables, we constructed the following new models for ROA and ROE.

$$
\begin{aligned}
\mathrm{ROA}_{t}=\beta_{o}+ & \beta_{1}(G D P)_{t}+\beta_{2}(I N F)_{t}+\beta_{3}(I N T)_{t} \\
& +\beta_{4}(S I Z e)_{t}+\beta_{5}\left(C A Q^{*}\right)_{t}+\beta_{6}(C O S T)_{t}+\beta_{7}\left(I N T^{*}\right)_{t}+\beta_{8}(D A R)_{t}+\beta_{9}(N I I)_{t} \\
& +e \\
\mathrm{ROE}_{t}=\beta_{o}+ & \beta_{1}(G D P)_{t}+\beta_{2}(I N F)_{t}+\beta_{3}(I N T)_{t} \\
& +\beta_{4}(S I Z e)_{t}+\beta_{5}\left(C A Q^{*}\right)_{t}+\beta_{6}(C O S T)_{t}+\beta_{7}\left(I N T^{*}\right)_{t}+\beta_{8}(D A R)_{t}+\beta_{9}(N I I)_{t} \\
& +e
\end{aligned}
$$

\subsection{Augmented Dickey Fuller \& Co-Integration Testing}

The results of the ADF test are shown in Table 3. 
Table 3. Augmented Dickey Fuller \& Co-Integration testing

\begin{tabular}{|c|c|c|c|c|c|c|c|c|c|c|c|c|}
\hline & $\begin{array}{l}\text { Bank } \\
\text { Name }\end{array}$ & & Size & CAQ & DAR & COSR & INT* & NII & ROA & ROE & $\begin{array}{c}\text { Residuals } \\
\text { (ROA) }\end{array}$ & $\begin{array}{c}\text { Residuals } \\
\text { (ROE) }\end{array}$ \\
\hline \multirow{10}{*}{ 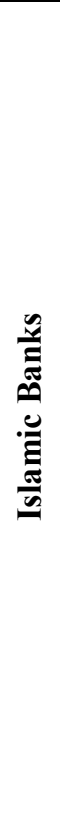 } & \multirow{2}{*}{$\begin{array}{l}\text { Al-Bar } \\
\text { aka }\end{array}$} & T-Stat & -10.62 & -9.86 & -4.74 & -7.04 & -4.05 & -6.36 & -4.26 & -14.2 & -6.331 & -6.724 \\
\hline & & P-Value & $\begin{array}{c}0.00^{*} \\
\mathrm{I}(1)\end{array}$ & $\begin{array}{c}0.01 * * \\
\mathrm{I}(1)\end{array}$ & $\begin{array}{c}0.05^{* *} \\
\mathrm{I}(1)\end{array}$ & $\begin{array}{c}0.00^{*} \\
\mathrm{I}(1)\end{array}$ & $\begin{array}{c}0.00^{*} \\
\mathrm{I}(1)\end{array}$ & $\begin{array}{l}.01^{* *} \\
\mathrm{I}(1)\end{array}$ & $\begin{array}{c}0.00^{*} \\
\mathrm{I}(0)\end{array}$ & $\begin{array}{c}.02 * * \\
\mathrm{I}(1)\end{array}$ & 0.003 & 0.000 \\
\hline & \multirow[t]{2}{*}{ Burj } & T-Stat & -9.40 & -2.98 & -8.36 & -4.71 & -8.58 & -5.55 & -3.28 & -3.44 & -4.213 & -4.074 \\
\hline & & P-Value & $\begin{array}{c}0.04 * * \\
\mathrm{I}(1)\end{array}$ & $\begin{array}{c}0.04 * * \\
\mathrm{I}(1)\end{array}$ & $\begin{array}{l}.01^{* *} \\
\mathrm{I}(1)\end{array}$ & $\begin{array}{l}0.00^{*} \\
\mathrm{I}(0)\end{array}$ & $\begin{array}{c}0.00^{*} \\
\mathrm{I}(1)\end{array}$ & $\begin{array}{l}.01 * * \\
\mathrm{I}(1)\end{array}$ & $\begin{array}{c}0.02 * * \\
\mathrm{I}(0)\end{array}$ & $\begin{array}{c}0.01 * * \\
\mathrm{I}(0)\end{array}$ & 0.000 & 0.006 \\
\hline & \multirow[t]{2}{*}{ Dubai } & T-Stat & -11.27 & -12.27 & -9.55 & -5.55 & -4.86 & -5.09 & -5.39 & -20.7 & -5.295 & -10.395 \\
\hline & & P-Value & $\begin{array}{c}0.00^{*} \\
\mathrm{I}(1)\end{array}$ & $\begin{array}{c}0.00^{*} \\
\mathrm{I}(1)\end{array}$ & $\begin{array}{c}.01^{* *} \\
\mathrm{I}(1)\end{array}$ & $\begin{array}{l}0.00^{*} \\
\mathrm{I}(1)\end{array}$ & $\begin{array}{c}0.00^{*} \\
\mathrm{I}(0)\end{array}$ & $\begin{array}{r}0.00^{*} \\
\mathrm{I}(0)\end{array}$ & $\begin{array}{c}.05^{* *} \\
\mathrm{I}(0)\end{array}$ & $\begin{array}{c}0.00^{*} \\
\mathrm{I}(0)\end{array}$ & 0.000 & 0.005 \\
\hline & \multirow[t]{2}{*}{ Islami } & T-Stat & -4.68 & -6.29 & -6.34 & -7.69 & -6.16 & -2.89 & -2.96 & -7.95 & -4.907 & -4.344 \\
\hline & & P-Value & $\begin{array}{l}0.00^{*} \\
\mathrm{I}(0)\end{array}$ & $\begin{array}{c}0.00^{*} \\
\mathrm{I}(0)\end{array}$ & $\begin{array}{c}0.00^{*} \\
\mathrm{I}(0)\end{array}$ & $\begin{array}{l}0.00^{*} \\
\mathrm{I}(0)\end{array}$ & $\begin{array}{c}0.00^{*} \\
\mathrm{I}(0)\end{array}$ & $\begin{array}{c}.05^{* *} \\
\mathrm{I}(0)\end{array}$ & $\begin{array}{c}0.04 * \\
\mathrm{I}(0)\end{array}$ & $\begin{array}{c}0.00^{*} \\
\mathrm{I}(1)\end{array}$ & 0.005 & 0.003 \\
\hline & \multirow[t]{2}{*}{ Meezan } & T-Stat & -3.49 & -7.99 & -8.73 & -3.62 & -3.43 & -2.21 & -3.70 & -3.51 & -5.916 & -5.952 \\
\hline & & P-Value & $\begin{array}{c}0.01 * * \\
\mathrm{I}(0)\end{array}$ & $\begin{array}{c}0.04 * * \\
\mathrm{I}(1)\end{array}$ & $\begin{array}{c}0.00^{*} \\
\mathrm{I}(1)\end{array}$ & $\begin{array}{l}0.00^{*} \\
\mathrm{I}(0)\end{array}$ & $\begin{array}{c}.01^{* *} \\
\mathrm{I}(0)\end{array}$ & $\begin{array}{c}0.00^{*} \\
\mathrm{I}(0)\end{array}$ & $\begin{array}{c}0.00^{*} \\
\mathrm{I}(0)\end{array}$ & $\begin{array}{c}.01^{* *} \\
\mathrm{I}(0)\end{array}$ & 0.006 & 0.007 \\
\hline \multirow{10}{*}{ 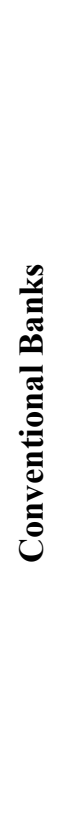 } & \multirow[t]{2}{*}{$F W B$} & T-Stat & -11.63 & -3.42 & -4.27 & -7.11 & -4.22 & -5.74 & -9.91 & -12.9 & -6.026 & -6.103 \\
\hline & & P-Value & $\begin{array}{l}0.00^{*} \\
\mathrm{I}(1)\end{array}$ & $\begin{array}{c}0.01^{* *} \\
\mathrm{I}(0)\end{array}$ & $\begin{array}{c}0.00^{*} \\
\mathrm{I}(0)\end{array}$ & $\begin{array}{l}0.00^{*} \\
\mathrm{I}(1)\end{array}$ & $\begin{array}{c}0.00^{*} \\
\mathrm{I}(1)\end{array}$ & $\begin{array}{l}.03^{* *} \\
\mathrm{I}(1)\end{array}$ & $\begin{array}{l}.02^{* *} \\
\mathrm{I}(1)\end{array}$ & $\begin{array}{c}0.00^{*} \\
\mathrm{I}(1)\end{array}$ & 0.007 & 0.005 \\
\hline & \multirow[t]{2}{*}{ Silk } & T-Stat & -13.02 & -10.75 & -8.16 & -7.50 & -4.41 & -12.3 & -4.77 & -5.09 & -5.667 & -5.666 \\
\hline & & P-Value & $\begin{array}{l}0.00^{*} \\
\mathrm{I}(1)\end{array}$ & $\begin{array}{c}0.01 * * \\
\mathrm{I}(1)\end{array}$ & $\begin{array}{c}.02^{* *} \\
\mathrm{I}(1)\end{array}$ & $\begin{array}{l}0.00^{*} \\
\mathrm{I}(0)\end{array}$ & $\begin{array}{c}0.00^{*} \\
\mathrm{I}(0)\end{array}$ & $\begin{array}{c}0.00^{*} \\
\mathrm{I}(1)\end{array}$ & $\begin{array}{c}0.00^{*} \\
\mathrm{I}(0)\end{array}$ & $\begin{array}{c}0.00^{*} \\
\mathrm{I}(0)\end{array}$ & 0.004 & 0.007 \\
\hline & \multirow[t]{2}{*}{ Citi } & T-Stat & -9.09 & -8.40 & -4.79 & -6.12 & -9.07 & -6.91 & -3.01 & -2.89 & -6.599 & -6.784 \\
\hline & & P-Value & $\begin{array}{l}0.00^{*} \\
\mathrm{I}(1)\end{array}$ & $\begin{array}{c}0.01^{* *} \\
\mathrm{I}(1)\end{array}$ & $\begin{array}{l}0.00 \\
\mathrm{I}(0)\end{array}$ & $\begin{array}{l}0.00^{*} \\
\mathrm{I}(0)\end{array}$ & $\begin{array}{c}0.00^{*} \\
\mathrm{I}(1)\end{array}$ & $\begin{array}{c}0.00^{*} \\
\mathrm{I}(0)\end{array}$ & $\begin{array}{c}.04^{* *} \\
\mathrm{I}(0)\end{array}$ & $\begin{array}{l}.05^{* *} \\
\mathrm{I}(0)\end{array}$ & 0.003 & 0.003 \\
\hline & \multirow[t]{2}{*}{ Samba } & T-Stat & 6.16 & -5.76 & -5.85 & -3.69 & -8.55 & -7.50 & -10.4 & -9.21 & -8.011 & -6.113 \\
\hline & & P-Value & $\begin{array}{c}0.04 * * \\
\mathrm{I}(0)\end{array}$ & $\begin{array}{c}0.00^{*} \\
\mathrm{I}(0)\end{array}$ & $\begin{array}{c}0.00^{*} \\
\mathrm{I}(0)\end{array}$ & $\begin{array}{l}0.00^{*} \\
\mathrm{I}(0)\end{array}$ & $\begin{array}{c}0.00^{*} \\
\mathrm{I}(0)\end{array}$ & $\begin{array}{c}0.00^{*} \\
\mathrm{I}(0)\end{array}$ & $\begin{array}{c}0.00^{*} \\
\mathrm{I}(0)\end{array}$ & $\begin{array}{l}.01 * * \\
\mathrm{I}(1)\end{array}$ & 0.003 & 0.003 \\
\hline & \multirow{2}{*}{ Askari } & T-Stat & -7.79 & -8.94 & -5.51 & -6.15 & -5.08 & -6.34 & -5.5 & -4.25 & -5.163 & -4.964 \\
\hline & & P-Value & $\begin{array}{c}0.05^{* *} \\
\mathrm{I}(1)\end{array}$ & $\begin{array}{c}0.00^{*} \\
\mathrm{I}(1)\end{array}$ & $\begin{array}{c}0.00^{*} \\
\mathrm{I}(0)\end{array}$ & $\begin{array}{l}0.00^{*} \\
\mathrm{I}(0)\end{array}$ & $\begin{array}{c}0.00^{*} \\
\mathrm{I}(0)\end{array}$ & $\begin{array}{c}0.00^{*} \\
\mathrm{I}(0)\end{array}$ & $\begin{array}{c}0.00 * \\
\mathrm{I}(0)\end{array}$ & $\begin{array}{c}0.00^{*} \\
\mathrm{I}(0)\end{array}$ & 0.000 & 0.005 \\
\hline
\end{tabular}

\begin{tabular}{|c|c|c|c|c|c|}
\hline \multicolumn{7}{|c|}{ ADF \& Co-Integration Tests for Macro-Economic Variables } \\
\hline & CPI & INT & GDPGR & $\begin{array}{c}\text { Residuals } \\
\text { (ROA) }\end{array}$ & $\begin{array}{c}\text { Residuals } \\
\text { (ROE) }\end{array}$ \\
\hline T-Statistics & -12.87 & -11.07 & -42.94 & -7.65 & -9.45 \\
\hline $\boldsymbol{P}$-Value & $0.05^{* *}$ & $0.00^{*}$ & $0.04^{* *}$ & 0.00 & 0.00 \\
& $\mathrm{I}(0)$ & $\mathrm{I}(0)$ & $\mathrm{I}(0)$ & & \\
\hline
\end{tabular}

Note: * and ** shows $1 \%$ and $5 \%$ level of significance respectively. $I(0)$ and $I(\boldsymbol{I})$ show level and first difference respectively. 
As seen in Table 3, (Note 6), it is revealed that all variables are either integrated of order zero, $I(0)$ or integrated of order one, $I(1)$. For example, the first row in the upper part of the table summarizes the results for Bank Al-Barakah. The results for LSIZE, CAQ, DAR, COSR, INT, NII, and ROE are integrated of order one, $I(1)$, whereas ROA is integrated of order zero, $I$ (0).

Similarly, the last row of Table 3 summarizes the results for Askari Bank. Here, it is seen that only LSIZE \& CAQ are integrated of order one, I (1), while DAR, COSR, INT, NII, ROA \& ROE are integrated of order zero, $I(0)$. Thus, for all banks most of the variables appeared to be non-stationary. Therefore, it is important to test for co-integration. General to specific methodology is adopted to avoid missing variables bias. Now to avoid Spurious Regression problem, verifying the Long Run relation (using Co-integration) between the desired variables is necessary. The last two columns of table 3 indicate the results of co-integration test. As shown in the last two columns of table 3, the findings of residuals of the stationary series for ROA \& ROE allow us to advance to the next test. This confirms that long run relationship exists between the variables. The long run relationship between ROA \& ROE and all independent variables is observed.

\subsection{Results and Discussion of the Long Run Relationship}

\subsubsection{Results of the Long Run Relationship}

The results of the long run relationship between the various variables and bank performance measures are presented in Tables 4 and 5. In Table 4, the long run relationship between ROA and other variables is presented.

Table 4. Long Run relationship between ROA and independent variables

\begin{tabular}{|c|c|c|c|c|c|c|c|c|c|c|c|}
\hline & $\begin{array}{l}\text { Bank } \\
\text { Name }\end{array}$ & Statistics & GDP & CPI & INT & $\begin{array}{l}\text { Bank } \\
\text { Size }\end{array}$ & CAQ & COST & DAR & INT* & NII \\
\hline \multirow{10}{*}{ 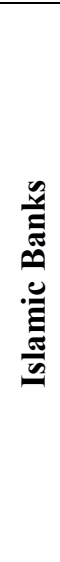 } & \multirow{2}{*}{$\begin{array}{l}\text { Al-Barak } \\
h\end{array}$} & T-Stat & 9.11 & 22.84 & -0.01 & 3.25 & -0.10 & -0.35 & 10.10 & 16.72 & 11.23 \\
\hline & & P-Value & 0.00 & 0.00 & 0.82 & 0.00 & 0.02 & 0.00 & 0.05 & 0.21 & 0.00 \\
\hline & \multirow[t]{2}{*}{ Burj } & T-Stat & 5.21 & 17.15 & -0.12 & -1.50 & 0.01 & -0.24 & 0.55 & 30.81 & 2.87 \\
\hline & & P-Value & 0.00 & 0.91 & 0.24 & 0.02 & 0.30 & 0.09 & 0.00 & 0.33 & 0.11 \\
\hline & \multirow[t]{2}{*}{ Dubai } & T-Stat & 7.18 & 27.72 & -3.04 & 11.53 & -0.04 & -0.19 & 0.96 & 15.71 & 4.74 \\
\hline & & P-Value & 0.00 & 0.03 & 0.22 & 0.00 & 0.00 & 0.05 & 0.04 & 0.41 & 0.03 \\
\hline & \multirow[t]{2}{*}{ Islami } & T-Stat & 8.09 & 10.92 & -0.03 & 6.05 & -88.03 & 0.01 & 14.01 & 19.13 & 5.52 \\
\hline & & P-Value & 0.00 & 0.00 & 0.89 & 0.09 & 0.06 & 0.81 & 0.04 & 0.12 & 0.02 \\
\hline & \multirow[t]{2}{*}{ Meezan } & T-Stat & 17.91 & 30.61 & -0.02 & 0.46 & -0.09 & -0.08 & 24.10 & 3.66 & 3.45 \\
\hline & & P-Value & 0.00 & 0.02 & 0.98 & 0.06 & 0.02 & 0.01 & 0.00 & 0.11 & 0.04 \\
\hline \multirow{3}{*}{$\begin{array}{l}\stackrel{\bar{z}}{\partial} \\
\bar{\Xi}\end{array}$} & \multirow[t]{2}{*}{$F W B$} & T-Stat & 5.04 & 16.64 & -0.01 & 9.77 & 0.05 & -0.01 & 74.99 & 24.12 & 10.49 \\
\hline & & P-Value & 0.00 & 0.01 & 0.48 & 0.00 & 0.03 & 0.04 & 0.00 & 0.03 & 0.01 \\
\hline & Silk & T-Stat & 8.05 & 21.05 & 0.09 & 2.83 & 0.17 & -0.04 & -0.02 & 30.11 & 15.56 \\
\hline
\end{tabular}




\section{Mll Macrothink}

\begin{tabular}{|l|l|l|c|c|c|c|c|c|c|c|c|}
\hline & P-Value & $\mathbf{0 . 0 3}$ & $\mathbf{0 . 0 4}$ & $\mathbf{0 . 1 4}$ & $\mathbf{0 . 0 5}$ & $\mathbf{0 . 0 4}$ & $\mathbf{0 . 2 2}$ & $\mathbf{0 . 4 0}$ & $\mathbf{0 . 0 0}$ & $\mathbf{0 . 0 2}$ \\
\cline { 2 - 11 } \multirow{2}{*}{ Citi } & T-Stat & 14.06 & 9.41 & -2.16 & 3.44 & 0.25 & -0.01 & 9.00 & 34.63 & 31.36 \\
\cline { 2 - 11 } & P-Value & $\mathbf{0 . 0 0}$ & $\mathbf{0 . 0 6}$ & $\mathbf{0 . 1 2}$ & $\mathbf{0 . 0 1}$ & $\mathbf{0 . 0 2}$ & $\mathbf{0 . 7 1}$ & $\mathbf{0 . 0 8}$ & $\mathbf{0 . 0 0}$ & $\mathbf{0 . 0 0}$ \\
\hline \multirow{2}{*}{ Samba } & T-Stat & 16.07 & 18.77 & -9.04 & 33.59 & 0.88 & -0.35 & 1.13 & 52.80 & 30.66 \\
\cline { 2 - 11 } & P-Value & $\mathbf{0 . 0 0}$ & $\mathbf{0 . 0 2}$ & $\mathbf{0 . 0 1}$ & $\mathbf{0 . 0 0}$ & $\mathbf{0 . 0 0}$ & $\mathbf{0 . 0 0}$ & $\mathbf{0 . 0 1}$ & $\mathbf{0 . 0 0}$ & $\mathbf{0 . 0 2}$ \\
\hline \multirow{2}{*}{ Askari } & T-Stat & 8.02 & 11.84 & -0.06 & -0.95 & -0.00 & 0.02 & 0.01 & -0.76 & 23.04 \\
\cline { 2 - 11 } & P-Value & $\mathbf{0 . 0 4}$ & $\mathbf{0 . 0 4}$ & $\mathbf{0 . 9 4}$ & $\mathbf{0 . 4 3}$ & $\mathbf{0 . 8 4}$ & $\mathbf{0 . 0 0}$ & $\mathbf{0 . 2 3}$ & $\mathbf{0 . 9 6}$ & $\mathbf{0 . 0 0}$ \\
\hline
\end{tabular}

The results in the Table above show that there is a significant long run relationship between return on assets (ROA) and seven determinants (GDP, CPI, Bank Size, CAQ, COST, DAR, INT* and NII). Only Interest Rate (INT), is found to be statistically insignificant.

Table 5 presents the results of the long run relationship between return on equity and the macroeconomic and bank specific variables in our model.

Table 5. Long Run relationship between ROE and independent variables

\begin{tabular}{|c|c|c|c|c|c|c|c|c|c|c|c|}
\hline & $\begin{array}{l}\text { Bank } \\
\text { Name }\end{array}$ & Statistics & GDP & CPI & INT & $\begin{array}{l}\text { Bank } \\
\text { Size }\end{array}$ & CAQ & COST & DAR & INT $^{*}$ & NII \\
\hline \multirow{10}{*}{ 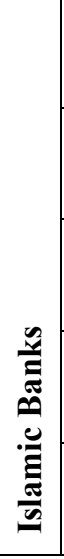 } & \multirow{2}{*}{$\begin{array}{l}\text { Al-Barak } \\
\text { ah } \\
\end{array}$} & T-Stat & 5.11 & 7.77 & -0.03 & 65.29 & -63.87 & -0.52 & 0.02 & 22.96 & 11.23 \\
\hline & & P-Value & 0.00 & 0.02 & 0.96 & 0.06 & 0.02 & 0.02 & 0.87 & 0.30 & 0.00 \\
\hline & \multirow[t]{2}{*}{ Burj } & T-Stat & 7.21 & 4.84 & -0.60 & 88.02 & -9.02 & -0.91 & 0.01 & 14.81 & 21.87 \\
\hline & & P-Value & 0.00 & 0.04 & 0.31 & 0.00 & 0.06 & 0.00 & 0.76 & 0.32 & 0.01 \\
\hline & \multirow[t]{2}{*}{ Dubai } & T-Stat & 11.18 & 3.05 & -3.20 & 0.59 & 0.06 & -0.09 & -0.02 & 2.98 & 4.74 \\
\hline & & P-Value & 0.00 & 0.27 & 0.18 & 0.82 & $\mathbf{0 . 0 3}$ & 0.07 & 0.98 & 0.88 & 0.03 \\
\hline & \multirow[t]{2}{*}{ Islami } & T-Stat & 32.33 & 9.91 & 0.02 & 16.00 & -2.43 & -0.02 & 0.13 & 26.73 & 5.52 \\
\hline & & P-Value & 0.00 & 0.00 & 0.98 & 0.06 & 0.09 & 0.67 & 0.05 & 0.20 & 0.02 \\
\hline & \multirow[t]{2}{*}{ Meezan } & T-Stat & 9.91 & 2.35 & -0.03 & 1.14 & 0.03 & -1.21 & 0.19 & 49.08 & 33.45 \\
\hline & & P-Value & 0.00 & 0.04 & 0.92 & 0.87 & 0.97 & 0.01 & 0.38 & 0.76 & 0.04 \\
\hline & & & & & & & & & & & \\
\hline \multirow{10}{*}{ 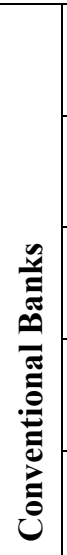 } & \multirow[t]{2}{*}{ Al-Falah } & T-Stat & 17.09 & 11.98 & -0.39 & -19.85 & -0.05 & -0.18 & 0.07 & 492.37 & 10.49 \\
\hline & & P-Value & 0.00 & 0.06 & 0.42 & 0.26 & 0.91 & 0.06 & 0.60 & 0.02 & 0.06 \\
\hline & \multirow[t]{2}{*}{ Askari } & T-Stat & 4.05 & -8.96 & -1.81 & 68.94 & 51.05 & -0.07 & -0.23 & 1085.52 & 15.06 \\
\hline & & P-Value & 0.03 & 0.07 & 0.17 & 0.03 & 0.00 & 0.24 & 0.65 & 0.00 & 0.02 \\
\hline & \multirow[t]{2}{*}{ Habib } & T-Stat & 33.06 & 5.62 & -1.88 & 47.02 & 3.07 & -0.44 & 0.23 & 1023.23 & 11.36 \\
\hline & & P-Value & 0.00 & 0.05 & 0.12 & 0.07 & 0.04 & 0.00 & 0.47 & 0.04 & 0.05 \\
\hline & \multirow[t]{2}{*}{ Muslim } & T-Stat & 8.07 & 7.93 & 9.64 & 27.53 & 2.11 & -0.34 & 0.11 & 773.74 & 22.06 \\
\hline & & P-Value & 0.00 & 0.03 & 0.00 & 0.00 & 0.08 & 0.07 & 0.02 & 0.00 & 0.02 \\
\hline & \multirow[t]{2}{*}{ United } & T-Stat & 19.02 & -2.11 & -2.15 & -18.62 & 0.89 & -0.29 & 0.17 & 29.34 & 13.04 \\
\hline & & P-Value & 0.04 & 0.36 & 0.67 & 0.10 & 0.05 & 0.00 & 0.15 & 0.85 & 0.07 \\
\hline
\end{tabular}


The results emerging from this model show a significant long run relationship between ROE and six variables namely GDP growth (GDP), CPI, Bank Size, CAQ, COST and INT* and $\mathrm{NII}$ in the long run. The remaining three variables are insignificant.

\subsubsection{Discussion of Results of the Long Run Relationship}

GDP growth is statistically significant and positively related to banking performance (ROA $\&$ ROE), as shown in table 5. The regression results for all ten banks represent positive and significant P-values. Thus, a rise in GDP growth increases the profitability for slamic and Conventional banks. This implies that during economic booms, all ten banks have gained significant profits. The positive impact of GDP growth supports the argument of the positive association between growth and financial sector performance, this is in line with the studies of Kosmidou et al. (2006) and Hassan and Bashir (2003). The results are highly significant for ROA and ROE in both banking systems. Hence, we learned that there is no major differential impact of GDP growth between Islamic and Conventional banks.

Going back to table 4 and 5, inflation (CPI) is found statistically significant and positively related to ROA and ROE. The regression results for all ten banks represent positive and significant P-values. This means that if inflation is properly anticipated, it gives banks the chance to adjust their interest rates accordingly, which results in higher revenues and profitability. The same results are supported by many other studies for example Athanasoglou et al. (2008); Kosmidou et al. (2006); Pasiouras et al. (2007); Haron and Wan (2004); Demirguc-Kunt and Huizinga (1999).

Similarly, Interest rate (INT) shows a negative but insignificant relationship with ROA \& ROE in both banking systems, which implies that interest rate does not play any important role in profit generation of banks. The negative sign suggests that an unanticipated increase in interest rate discourages bank customers from borrowing, increases borrowers' interest payments and thereby decreases their repayment ability, which means the number of defaulters' increases. It ultimately decreases bank profitability. This finding is consistent with those of Gordon (1981); Wadhwani (1986) and Zeitun, Tian and Keen (2007).

In table 4 and 5 , both estimated equations indicate that profitability is influenced by bank size, because the results are statistically significant for all the ten banks. The positive sign is an indication of economy of scales. A positive impact of size can be related with profitability because economies of scale may decrease the cost of processing and collecting the information (Boyd, 1993). The study is consistent with most of the previous studies including Kahf (2004); Al-Tamimi (2005); Kosmidou, (2005) and Sufian and Habibullah (2010).

As shown in the upper part of In tables $4 \& 5$, the sign of coefficient for most of the Islamic banks is negative and statistically significant. This negative sign implies a weaker position of Islamic Banks in terms of capital adequacy (CAQ) as compared to their conventional counterparts. By contrast, at the lower part of the tables both estimated models suggest that profitability has a positive and significant relationship with ROA and ROE for conventional banks. This implies that conventional banks are stronger in responding to balance sheet shocks, such as liability payments; operational costs and credit risks or any other losses. The 
positive association between capital and performance of conventional banks was also confirmed by (Bashir, 2003; Haron 2004; Kosmidou, 2007).

The results indicate that COST has a negative and significant relationship with profitability measures (ROA \& ROE) as shown in table 4 and 5. Berger (1995) argued that the inverse relation of expenditures with profits shows that expenditures are not being managed efficiently. In other words poor expense management increases the cost of operations and decreases income. This is because of the fact that competition is a major obstacle and do not allow the banks "overcharge". There seems to be no contradiction between Shariah and non-Sharia banks with regards to COST as its impact is negative and significant for both profitability measures in both types of banking systems. This study is consistent with Kosmidou, (2005); and Sufian and Habibullah (2010); Ramadan, Kilani and Kadumi (2011) and Teng et al. (2012).

DAR has significant and positive relationship with the ROA as shown in table 4 for both types of banks. However, it is found to be positive and insignificant with ROE as shown in table 5. The results show that it is also a major determinant of performance. This implies that banks that are reliant on deposits rather than on equity or other sources can sustain higher ROA. These results were previously documented by Javaid, et al. (2011) and Gul, et al. (2011).

Referring to table 4 and 5, it is observed that INT* has positive and significant relationship with ROA \& ROE for all five conventional banks, which are presented in the lower part of the table. This implies that with respect to management efficiency, conventional banks make better and profitable investment decisions, attracting more profits for conventional banks and stakeholders. By contract, INT* is positive but insignificant in case of Islamic banks. This means that Islamic banks are less profitable due to poor investment decisions. The finding also implies that Sharia banks lack management ability, which is more concentrated on expansion and development strategies and not on profitable policies (Jaffar \& Manarvi 2011). The results indicate that Islamic banks in Pakistan should concentrate on how to increase their net interest income or margin.

Consistent with the theories and literature, there is positive relation between non-interest income and bank profitability in both types of banking systems. The positive relation of NII over ROA and ROE could be attributed to the fact that Pakistan's banking sector is undergoing a gradual transformation from the traditional business of deposit and lending and financial intermediation towards provision of other financial services including safe keeping, ATM charges, currency exchange and modern money transfer system etc. 
4.5.3 Results and Discussion of the Short Run Relationship

Table 6. Short Run relationship between ROA and independent variables

\begin{tabular}{|c|c|c|c|c|c|c|c|c|c|c|c|}
\hline & Bank Name & Statistics & GDP & CPI & INT & $\begin{array}{l}\text { Bank } \\
\text { Size }\end{array}$ & CAQ & $\begin{array}{l}\text { COS } \\
T\end{array}$ & DAR & INT* & NII \\
\hline \multirow{10}{*}{ 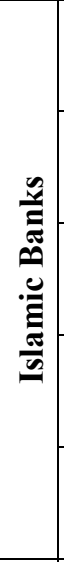 } & \multirow[t]{2}{*}{ Al-Barakh } & T-Stat & 45.15 & 3.10 & 2.03 & -0.24 & -0.01 & 0.01 & 10.10 & 171.66 & 10.02 \\
\hline & & P-Value & 0.01 & 0.20 & 0.03 & 0.00 & 0.34 & 0.62 & 0.05 & 0.000 & 0.03 \\
\hline & \multirow[t]{2}{*}{ Burj } & T-Stat & 9.19 & -5.01 & 3.69 & 0.05 & -0.04 & 0.01 & 0.55 & 37.01 & 12.01 \\
\hline & & P-Value & 0.02 & 0.93 & 0.02 & 0.04 & 0.04 & 0.62 & 0.00 & 0.05 & 0.06 \\
\hline & \multirow[t]{2}{*}{ Dubai } & T-Stat & -6.04 & 11.03 & 5.12 & -0.05 & -0.06 & -0.02 & 0.96 & 17.06 & 9.01 \\
\hline & & P-Value & 0.12 & 0.41 & 0.00 & 0.00 & 0.02 & 0.04 & 0.04 & 0.00 & 0.00 \\
\hline & \multirow[t]{2}{*}{ Islami } & T-Stat & 50.08 & -9.04 & 0.14 & 0.03 & 0.00 & 0.01 & 14.01 & 8.86 & 0.03 \\
\hline & & P-Value & 0.00 & 0.28 & 0.83 & 0.75 & 0.84 & 0.56 & 0.04 & 0.44 & 0.03 \\
\hline & \multirow[t]{2}{*}{ Meezan } & T-Stat & 32.13 & 25.02 & 7.33 & -0.06 & -0.06 & 0.00 & 24.10 & -6.90 & 11.02 \\
\hline & & P-Value & 0.04 & 0.80 & 0.01 & 0.63 & 0.01 & 0.98 & 0.00 & 0.42 & 0.04 \\
\hline \multirow{10}{*}{ 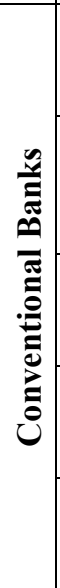 } & \multirow{2}{*}{ Al-Falah } & T-Stat & 7.91 & 15.07 & 1.18 & 0.08 & 0.01 & 0.01 & 30.24 & 30.24 & 7.02 \\
\hline & & P-Value & 0.00 & 0.01 & 0.05 & 0.00 & 0.01 & 0.38 & 0.00 & 0.00 & 0.04 \\
\hline & \multirow[t]{2}{*}{ Askari } & T-Stat & 44.08 & 6.04 & 3.03 & 0.28 & 0.04 & -0.01 & 26.26 & 26.26 & 21.03 \\
\hline & & P-Value & 0.05 & 0.57 & 0.00 & 0.05 & 0.02 & 0.64 & 0.00 & 0.27 & 0.00 \\
\hline & \multirow[t]{2}{*}{ Habib } & T-Stat & 10.02 & -8.06 & 5.63 & 0.44 & 0.02 & 0.04 & -11.87 & -11.87 & 14.03 \\
\hline & & P-Value & 0.73 & 0.60 & 0.03 & 0.00 & 0.91 & 0.05 & 0.83 & 0.83 & 0.03 \\
\hline & \multirow[t]{2}{*}{ Muslim } & T-Stat & 7.04 & -4.02 & -0.29 & 0.07 & -0.34 & 0.01 & 53.40 & 53.40 & 10.01 \\
\hline & & P-Value & 0.04 & 0.51 & 0.63 & 0.06 & 0.00 & 0.19 & 0.00 & 0.00 & 0.01 \\
\hline & \multirow[t]{2}{*}{ United } & T-Stat & 12.01 & -9.02 & -0.18 & -0.03 & 0.02 & 0.01 & 6.71 & 6.71 & 7.01 \\
\hline & & P-Value & 0.60 & 0.57 & 0.80 & 0.41 & 0.00 & 0.37 & 0.36 & 0.36 & 0.07 \\
\hline
\end{tabular}

Table 7. Short Run relationship between ROE and Independent Variables

\begin{tabular}{|c|c|c|c|c|c|c|c|c|c|c|c|}
\hline & $\begin{array}{l}\text { Bank } \\
\text { Name }\end{array}$ & Statistics & GDP & CPI & INT & $\begin{array}{l}\text { Bank } \\
\text { Size } \\
\end{array}$ & CAQ & COST & DAR & INT* $^{*}$ & NII \\
\hline \multirow{10}{*}{ 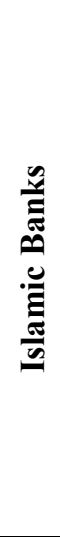 } & \multirow[t]{2}{*}{ Al-Barakh } & T-Stat & 23.95 & -9.07 & 20.74 & 16.95 & -1.49 & -0.02 & 0.08 & 1604.2 & 11.02 \\
\hline & & P-Value & 0.06 & 0.76 & 0.34 & 0.05 & 0.04 & 0.45 & 0.60 & 0.00 & 0.04 \\
\hline & \multirow[t]{2}{*}{ Burj } & T-Stat & 19.83 & -8.07 & 34.01 & 8.85 & 0.11 & -0.02 & 0.001 & 166.43 & 5.12 \\
\hline & & P-Value & 0.07 & 0.70 & 0.98 & 0.00 & 0.38 & 0.60 & 0.94 & 0.14 & 0.00 \\
\hline & \multirow[t]{2}{*}{ Dubai } & T-Stat & 8.26 & 10.02 & 13.04 & 3.29 & 0.07 & -0.01 & 0.02 & -4.38 & 21 \\
\hline & & P-Value & 0.00 & 0.46 & 0.69 & 0.03 & 0.00 & 0.53 & 0.46 & 0.58 & 0.00 \\
\hline & \multirow[t]{2}{*}{ Islami } & T-Stat & 7.43 & 11.19 & 7.36 & 4.41 & 0.31 & -0.01 & 0.11 & 109.87 & 8.22 \\
\hline & & P-Value & 0.01 & 0.05 & 0.18 & 0.29 & 0.02 & 0.58 & 0.37 & 0.15 & 0.00 \\
\hline & \multirow[t]{2}{*}{ Meezan } & T-Stat & 11.31 & 15.15 & -7.56 & -2.93 & -0.53 & -1.10 & 0.06 & -127.3 & 9.21 \\
\hline & & P-Value & 0.27 & 0.35 & 0.20 & 0.70 & 0.49 & 0.00 & 0.71 & 0.28 & 0.00 \\
\hline
\end{tabular}




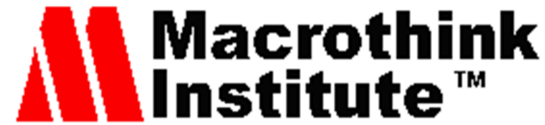

\begin{tabular}{|c|c|c|c|c|c|c|c|c|c|c|c|}
\hline \multirow{10}{*}{ 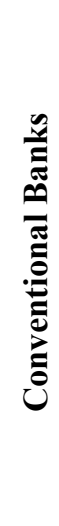 } & \multirow[t]{2}{*}{ Al-Falah } & T-Stat & 6.30 & 20.26 & -5.32 & 23.29 & 0.82 & -0.18 & 0.07 & 583.9 & 16.95 \\
\hline & & P-Value & 0.36 & 0.11 & 0.01 & 0.06 & 0.04 & $\mathbf{0 . 0 0}$ & 0.49 & 0.00 & 0.05 \\
\hline & \multirow[t]{2}{*}{ Askari } & T-Stat & 3.48 & -6.38 & 9.62 & 64.84 & 5.91 & -0.08 & -0.10 & 590.87 & 8.85 \\
\hline & & P-Value & 0.07 & 0.41 & 0.64 & 0.00 & 0.04 & 0.02 & 0.69 & 0.02 & 0.00 \\
\hline & \multirow[t]{2}{*}{ Habib } & T-Stat & 21.27 & -8.30 & -5.71 & 6.96 & 4.03 & 0.04 & 0.48 & 26.69 & 3.29 \\
\hline & & P-Value & 0.71 & 0.40 & 0.57 & 0.73 & 0.01 & 0.87 & 0.05 & 0.96 & 0.03 \\
\hline & \multirow[t]{2}{*}{ Muslim } & T-Stat & 12.39 & 11.07 & -9.32 & 27.66 & -4.18 & -0.27 & 0.11 & 455.1 & 32.11 \\
\hline & & P-Value & 0.34 & 0.68 & 0.56 & 0.07 & 0.15 & $\mathbf{0 . 0 3}$ & 0.28 & 0.00 & 0.02 \\
\hline & \multirow[t]{2}{*}{ United } & T-Stat & 8.26 & 23.17 & 11.42 & 4.36 & -0.87 & -0.25 & 0.09 & 70.19 & 16.21 \\
\hline & & P-Value & 0.32 & 0.20 & 0.30 & 0.62 & 0.04 & 0.00 & 0.27 & 0.43 & 0.04 \\
\hline
\end{tabular}

Table 7 summarizes the results of short run relation between ROE and independent variables. The results show that in the short run, GDP, Bank Size, CAQ, INT* and NII impacts bank performance. However, COST is the only variable that is insignificant for Islamic Banks while it remains significant for conventional banks. The remaining three variables are insignificant for both types of banks.

\section{Conclusion}

This study has examined the impacts of macroeconomic factors on the performance of commercial banks of Pakistan for a period of 2007 to 2015. The findings of this study revealed that both types of banks have earned higher profits with economic boom or with a rise in GDP. This shows that throughout economic boom all the ten banks have witnessed significant profits. Furthermore, inflation (CPI) was also found to be statistically significant and positively related with performance. Interest rate (INT) shows a negative and insignificant impact over ROA \& ROE for both Islamic and Conventional banks, which imply that interest rate; do not play any important role in profit generation of banks. This suggests that an unanticipated increase in interest rate discourages bank customers from borrowing. Moreover, increase in bank size means that banks are enjoying the economy of scales leading the bank to additional earnings. The theory of economy of scale explains the negative connection between the bank size and ROA which implies that greater the size of bank, lesser the profits it earns. Coming to CAQ, we see that Islamic banks have negative and statistically significant relationship with profitability measures. This negative sign implies a weaker position of Islamic Banks in terms of capital adequacy (CAQ) as compared to their conventional counterparts. By contrast the findings of this study revealed that Capital Adequacy (CAQ) through Equity-to-Total Assets ratio had a positive and significant impact on banks' profitability both in the long-run and in the short run. We found that conventional banks are stronger in responding to balance sheet shocks, such as liability payments, operational and credit risks or any other losses. The findings also discovered a negative relationship COST and profitability. According to Berger (1995), the negative relation of expenses with returns suggests that there is lack of efficiency in expense management. Moreover, the study revealed that deposit to asset ratio is significant and positively related to profitability; this suggests that attracting more deposits can significantly increase profitability 
for both Islamic \& conventional banks. Interest income is significant and positively related to profitability. This implies that with respect to management efficiency, conventional banks make better and profitable investment decisions, attracting more profits for conventional banks and stakeholders. Islamic banks are less profitable due to poor investment decisions. Finally, the study revealed that there is a positive relation between non-interest income and bank profitability in both types of banking systems. The positive relation of net interest income over profitability could be attributed to the fact that Pakistan's banking sector is undergoing a gradual transformation away from the traditional business of deposit and lending. The findings of this comparative study shows that Islamic banks moved shoulder to shoulder with conventional banks and documented a considerable growth from 2007-2015. This suggests that equity based Islamic banking are profitable firms.

\section{Recommendations}

The findings of this study produce the following recommendations:

- It is observed that that GDP improves the performance of banks in terms of ROA and ROE. Therefore, banks should make policies to efficiently utilize the fruits of economic booms.

- Inflation proved to be a significant determinant of profitability; thus bank management should be able to properly anticipate inflation and should accordingly adjust their interest rates.

- Economies of scales derived from bank size play a crucial role in bank profitability. The benefit of size would reflect in the ability to reach wider markets. Banks should therefore be encouraged to look beyond local market and strategically expand their operations to other geographical markets and sectors of the economy.

- COST indicates a negative relationship with profitability; this means a decrease in profits or lack of management efficiency. Thus, banks should control their expenses by reducing operating, administrative and personnel expense through using common facilities such as ATM. Similarly, implementation and monitoring and good governance can improve the quality of management.

- Deposits contribute significantly to bank performance, thus Islamic banks should attract more customers and enlarge their deposition base to generate more profit.

\section{References}

Abreu, M., \& Mendes, V. (2001). Commercial bank interest margins and profitability: evidence for some EU countries. Paper presented at the Pan-European Conference Jointly Organised by the IEFS-UK \& University of Macedonia Economic \& Social Sciences, Thessaloniki, Greece, May.

Aburime, T. U. (2008). Determinants of bank profitability: company-level evidence from Nigeria. 
Ahmad, S., \& Nafees, B. (2010). Profitability of Domestic Pakistani Banks: Panel Data Evidence for the Period 2001-2010. University of Central Punjab, Pakistan, Lahore.

Akhtar, W. (2011). Efficiency and Performance of Islamic Banking: The Case of Pakistan. Far East Research Centre, Hong Kong.

Anbar, A., \& Alper, D. (2011). Bank specific and macroeconomic determinants of commercial bank profitability: Empirical evidence from Turkey. Business and Economics Research Journal, 2(2), 139-152.

Athanasoglou, P. P., Brissimis, S. N., \& Delis, M. D. (2005). Bank-specific, Industry-specific and Macroeconomic determinants of bank profitability. Working paper No. 25.

Athanasoglou, P. P., Sophocles, N. B., \& Delis, M. D. (2008). Bank-specific, industry-specific and macroeconomic determinants of bank profitability. International Financial Markets, Institutions and Money, $18(2)$. https://doi.org/10.1016/j.intfin.2006.07.001

Athanasoglou, P., Delis, M., \& Staikouras, C. (2006). Determinants of Bank profitability in the South Eastern European region. Munich Personal RePEc Archive (MPRA) Paper No. 10274.

Bikker, J. A., \& Hu, H. (2002). Cyclical patterns in profits, provisioning and lending of banks and procyclicality of the new Basel capital requirements. Banca Nazionale del Lavoro Quarterly Review, 55(221), 143.

Bobáková, I. (2003). Raising the profitability of commercial banks. BIATEC, 11, 21-25.

Chapra, M. U. (2007). 21 Challenges facing the Islamic financial industry. Handbook of Islamic Banking, 325. https://doi.org/10.4337/9781847205414.00032

Demirguc-Kunt, A., \& Detragiache, E. (2000). Monitoring Banking sector fragility: a multivariate logit approach. World Bank Economic Review, 14(2), 287-307. Oxford University Press. https://doi.org/10.1093/wber/14.2.287

Dietrich, A., \& Wanzenried, G. (2011). Determinants of bank profitability before and during the crisis: Evidence from Switzerland. Journal of international financial Markets, Institutions and Money, 21(3), 307-327. https://doi.org/10.1016/j.intfin.2010.11.002

Flamini, V., McDonald, C., \& Schumacher, L. (2009). The Determinants of Commercial Ban profitability in Sub-Saharan Africa. IMF working paper, (09/15). https://doi.org/10.5089/9781451871623.001

Gizycki, M. C. (2001). The effect of economic conditions on banks' risk and profitability: Reserve Bank of Australia.

Gul, S., Irshad, F., \& Zaman, K. (2011). Factors affecting Banking Profitbility In Pakistan. The Roman Economic Journal, 39, 61-87.

Haron, S., \& Azmi, W. (2004). Profitability determinants of islamic banks. Paper presented at 
the Islamic Banking Conference.

Hassan, A., \& Moin, Z. (2008). Macroeconomic Factors and Equity Prices an Empirical Investigation by using ARDL Approach. The Pakistan Development Review, 47(4), 501-513.

Hassan, M. K. (1999). Islamic banking in theory and practice: the experience of Bangladesh. Managerial Finance, 25(5), 60-113. https://doi.org/10.1108/03074359910765966

Hassan, M. K., \& Bashir, A.-H. M. (2003). Determinants of Islamic banking profitability. Paper presented at the 10th ERF Annual Conference, Morocco.

Heggestad, A. A., \& Mingo, J. J. (1976). Prices, nonprices, and concentration in commercial banking. Journal of money, credit and Banking, 8(1), 107-117. https://doi.org/10.2307/1991923

Husni, A. K., Walid, Z. S., \& Ali, H. K. (2011). Determinants of Islamic Bank Profitability: Evidence from Jordan. Middle Eastern Finance and Economics, 13.

Idrees, K. et al. (2011). Determinants of Islamic banking institutions' profitability in Malaysia. World Applied Sciences Journal, 12(Special Issue on Bolstering Economic Sustainability), $1-7$.

Iqbal, M. (2001). Islamic and Conventional Banking in Nineties: A comparative study. Islamic Economic Studies, 8(2).

Javaid, S. et al. (2011). Determinants of Bank Profitability in Pakistan: Internal Factor Analysis. Mediterranean Journal Of Social Sciences, 2(1), 59-78.

Kader, R. A., \& Leong, Y. K. (2009). The impact of interest rate changes on Islamic bank financing. International Review of Business Research Papers, 5(3), 189-201.

Kahf, M., \& Ahmad, K. (1980). A Contribution to the Theory of Consumer Behaviour in Islamic Society, Studies in Islamic Economics, Leicester: The Islamic Foundation.

Khan, F. et al. (2012). Growth of Islamic Banking in Pakistan: A Comparative Study. Research Journal of Finance and Accounting, 3(2).

Khan, M. A. et al. (2013). Operational Efficiency of Islamic Banks: The Case of Malaysia and Pakistan. Interdisciplinary Journal of Contemporary Research in Business, 5(3), 660-668.

Khrawish, H. A., \& Al-Sa'di, N. M. (2011). The Impact of E-banking on bank profitability: Evidence from Jordan. Middle Eastern Finance and Economics, (13), 142-158.

Kosmidou, K. (2008). The determinants of Bank's profit in Greece during the period of EU Financial Integration. Manegerial Finance, 34, 146-159. https://doi.org/10.1108/03074350810848036

Kosmidou, K., \& Zopounidis, C. (2008). Management of Bank performance in Greece. South-eastern Europ Journal of Economics, 1, 79-95. 
Kosmidou, K., Pasiouros, F., \& Tsaklanganos, A. (2007). Domestic and Multinational Determinants of forien Bank profit: The case of Greek banks operating abroad. Journal of Multinational Financial Management, 17, 1-15. https://doi.org/10.1016/j.mulfin.2006.02.002

Kunt, D., \& Huizinga, H. (1999). Determinants of Commercial Bank Interest Margins and Profitability: Some International Evidence. The World Bank Economic Review, 13(2), 379-408. https://doi.org/10.1093/wber/13.2.379

Kutsienyo, L. (2011). The determinant of profitability of banks in Ghana. Institute of Distance Learning, Kwame Nkrumah University of Science and Technology.

Lair, R. W. S. (2004). Macroeconomic Determinants of Banking Financial Performance and Resilience in Singapore (Vol. 38). Macroeconomic Surveillance Department, Monetary Authority of Singapore.

Laker, J. (1999). Monitoring financial system stability. Reserve Bank of Australia Bulletin, 10, 40-46.

Mamatzakis, E., \& Remoundos, P. (2003). Determinants of Greek commercial banks, 1989-2000. Spoudai, 53(1), 84-94.

Manzoor, M. M., Aqeel, M., \& Sattar, A. (2010). Factors Paving the Way Towards Islamic Banking in Pakistan. World Academy of Science, Engineering and Technology, 42, 1677.

Matthews, K., \& Ismail, M. (2006). Efficiency and productivity growth of domestic and foreign commercial banks in Malaysia. Cardiff economics working papers.

Miller, S. M., \& Noulas, A. G. (1996). The technical efficiency of large bank production. Journal of banking \& Finance, 20(3), 495-509. https://doi.org/10.1016/0378-4266(95)00017-8

Moin, M. S. (2008). Performance of Islamic banking and conventional banking in Pakistan: a comparative study.

Neely, M. C., \& Wheelock, D. C. (1997). Why does bank performance vary across states? Federal Reserve Bank of St. Louis Review, (Mar), 27-40.

Nienhaus, V. (1983). Profitability of Islamic PLS banks competing with interest banks: problems and prospects. Journal of Research in Islamic Economics, 1(1), 31-39.

Ommeren, S. (2011). An examination of the determinants of banks' profitability in the European banking sector. An Unpublished M. Sc. esis.

Rasiah, D. (2010). Review of literature and theories on determinants of commercial bank profitability. Journal of Performance Management, 23(1), 23.

Revell, J. (1979). Inflation \& Financial Institutions: Financial Times Limited.

Rose, A. K., \& Spiegel, M. M. (2002). A gravity model of sovereign lending: trade, default and credit. National Bureau of Economic Research. https://doi.org/10.3386/w9285 
Said, F., \& Ismail, A. (2005). Monetary Policy, Capital requirement and Lending Behaviour of Islamic Banks in Malaysia. Paper presented at the 3rd International Islamic Banking and Finance Conference.

Samad, A. (2004). Performance of Interest-free Islamic banks vis-à-vis Interest-based Conventional Banks of Bahrain. International Journal of Economics, Management and Accounting, 12(2).

Samad, A., \& Hassan, M. K. (1999). The performance of Malaysian Islamic bank during 1984-1997: An exploratory study. International Journal of Islamic Financial Services, 1(3), $1-14$.

Samuelson, P. A. (1945). The effect of interest rate on the banking system. The American Economic Review, 16-27.

Sastrosuwito, S., \& Suzuki, Y. (2011). Post Crisis Indonesian Banking System Profitability: Bank-Specific, Industry-Specific, and Macroeconomic Determinants. Makalah yang diseminarkan.

Singh, R. K., \& Chaudhary, S. (2009). Profitability determinants of banks in India. International Journal of Global Business, 2(1), 163-180.

Smirlock, M. (1985). Evidence on the (non) relationship between concentration and profitability in banking. Journal of money, credit and Banking, 17(1), 69-83. https://doi.org/10.2307/1992507

Sufian, F., \& Habibullah, M. S. (2010). Does economic freedom fosters banks' performance? Panel evidence from Malaysia. Journal of Contemporary Accounting \& Economics, 6(2), 77-91. https://doi.org/10.1016/j.jcae.2010.09.003

Teng, K. Y. et al. (2012). The Determinants Of Islamic Banks Profitability In Malaysia. Journal of Business and Finance Malaysia, 2(3), 25-58.

Vong, A. P., \& Chan, H. S. (2009). Determinants of bank profitability in Macao. Macau Monetary Research Bulletin, 12(6), 93-113.

Wasiuzzaman, S., \& Tarmizi, H.-A. B. A. (2010). Profitability of Islamic banks in Malaysia: An empirical analysis. Journal of Islamic Economics, Banking and Finance, 6(4), 53-56.

\section{Notes}

Note 1. The committee will include ten members.

Note 2. The latter relates to decisions that slightly contain elements of earning plus balance sheet and the former contains factors with no direct links to financial documents, for instance total branches, branch status and bank locality (Haron, 2004)

Note 3. An indicator of how much of bank assets are tied up in loans.

Note 4. Very important as it is the main source of funding for banks. 
Note 5. It is a pre-condition for maximizing bank profitability. Improper cost management reduces profitability. Literature suggests that better control over expenses promotes the bank's share in the market and profits Berger (1995); Athanasoglou et al, (2005); Bashir (2003), Haron (2004); and Ahmad (2011).

Note 6 . In order to obtain a meaningful regression analysis in time series data there is always need for unit root test to ensure stationarity of data. This is because time series data exhibit stochastic trends which may lead the OLS model to spurious regression. This spurious regression occurs when one non-stationary time series is regressed against another. To avoid this problem, we employ the Augmented Dickey-Fuller (ADF) test, which allows the differentiation of the variables of interest until the stationary condition is achieved.

\section{Copyrights}

Copyright for this article is retained by the author(s), with first publication rights granted to the journal.

This is an open-access article distributed under the terms and conditions of the Creative Commons Attribution license (http://creativecommons.org/licenses/by/4.0/). 